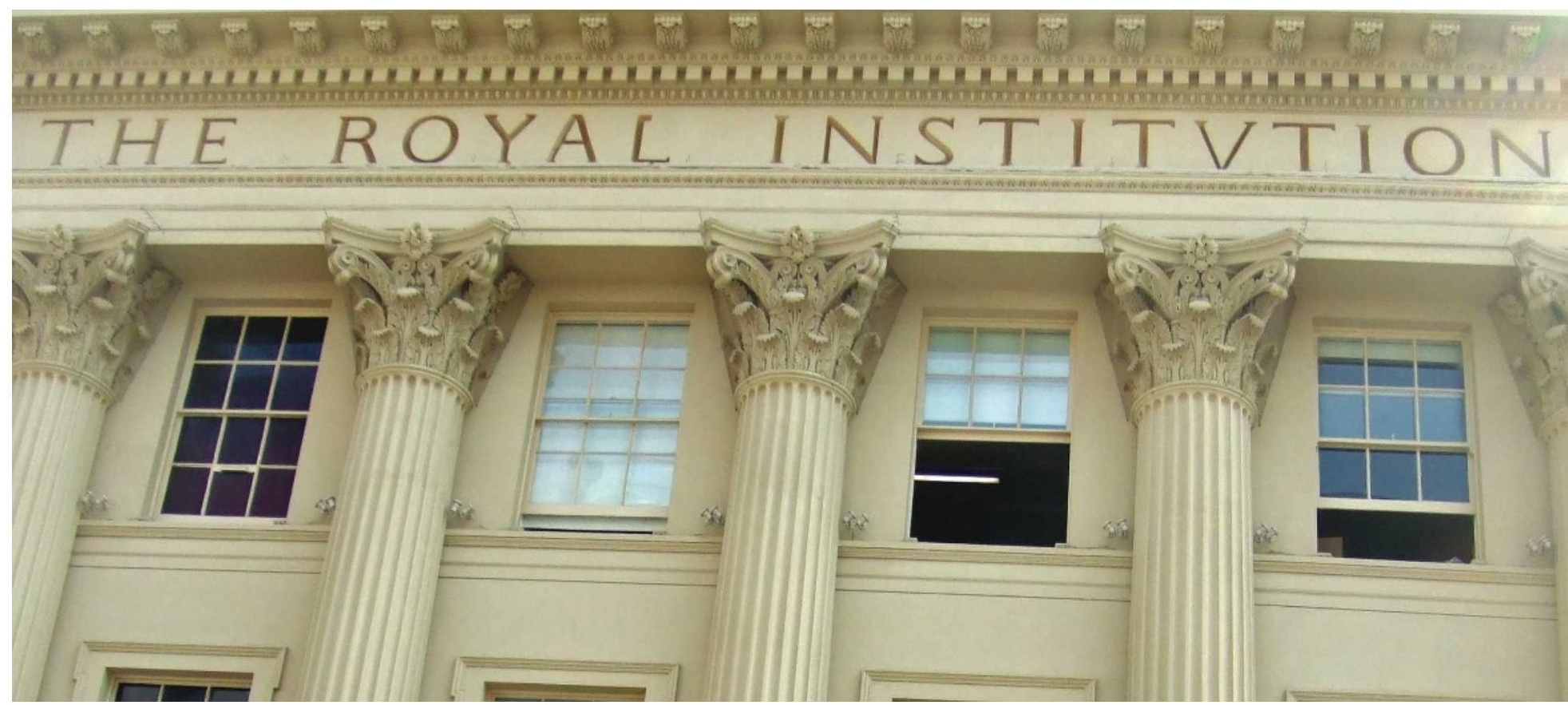

\title{
Venerable institute gets a refit
}

The oldest independent research body in the world, Britain's Royal Institution, has been committed since 1799 to "diffusing science for the common purposes of life". But some of the common purposes of life have changed in the past two centuries.

Visitors to the Royal Institution in London's Albemarle Street - which was once so besieged by carriages attending the popular scientific lectures that it was made the city's first one-way street - now require a more modern, broader variety of engagement, the Royal Institution's director believes. The palatial building, which has hosted exciting events such as the discovery of sodium and potassium by Humphrey Davy and electromagnetic induction by Michael Faraday, became run down and dilapidated over time.

So, time for a change. This week, after a $£ 22$-million (US\$44-million) refurbishment, the building - part public venue, part research laboratory - reopened to acclaim. A two-year restoration project to preserve the historic fabric of the building has seen major changes to public access and facilities. A café, bar and a hologram of Faraday now greet visitors to an institution that once struggled to offer the public so much as a cup of tea.

The aim, according to director Susan Greenfield, "is to position the Royal Institution at the centre of twenty-first- century society, where science will take its proper place at the heart of all our lives". Greenfield will retain her private apartment at the top of the building, a privilege of institution directors.

The Royal Institution is perhaps best known for its Christmas lectures, annual science talks for children that were started by Faraday in 1826 and reach a worldwide audience. But the institution is in a rare position of combining public engagement in science with a tradition of world-class research that has seen the discovery of ten chemical elements and bagged 14 Nobel prizes. A new team will soon settle into the institution's Davy-Faraday Research Laboratory (DFRL), where scientists pioneered $\mathrm{X}$-ray crystallography and the vacuum flask.

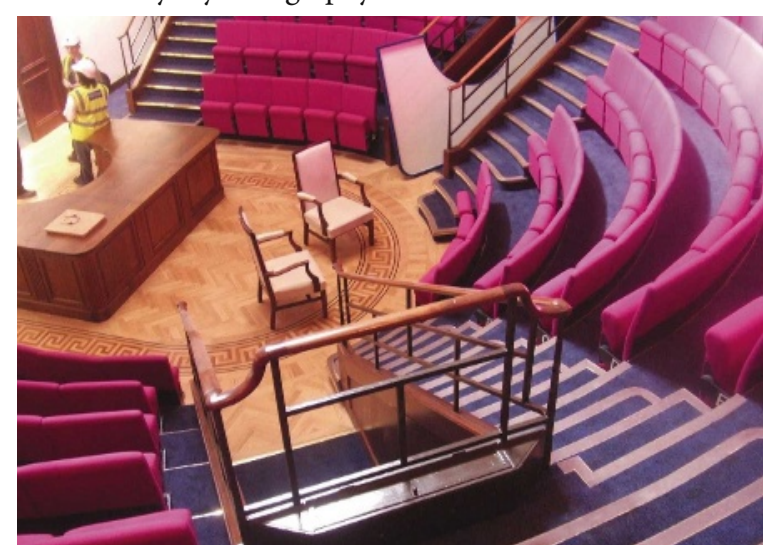

Greenfield, a neuroscientist who was appointed director in 1998, four years after becoming the first woman to deliver the Christ- $\sum_{\Sigma}^{\infty}$ mas lectures, has brought a new vision to the Royal Institution and increased the 'public engagement' operations. The constituency attending its events is now much wider than the academic and old-boys' networks of old. A lecture hall and cloakroom no longer suffice. The modern audience demands food, drink, entertainment and education from the same venue.

Architects at Terry Farrell and Partners have redesigned the building to meet these new needs. Walls have been knocked through to make way for a glass atrium and restaurant space. The museum sections of the basement have been refreshed to celebrate the institution's history and heritage. The Faraday lecture theatre, home to the Christmas lectures, is completely refurbished (see left). The $\sum_{\Sigma}^{\infty}$ venue can even be hired for weddings.

But although public access is improved, the number of scientists in the DFRL has been reduced from 60 to 15 . When the site closed for renovation, the laboratory moved temporarily to University College London (UCL). In the intervening two years, the group, headed by Richard Catlow, became "increasingly dependent on UCL's facilities" and has chosen to remain at UCL, a decision that all parties describe as amicable. 
But a former member of the laboratory, who wishes to remain anonymous, feels that the research group was increasingly squeezed out in favour of public engagement even before the refurbishments. He questions Greenfield's vision, and whether it was worth the institution selling its property assets to finance the changes. "Greenfield was right, the Royal Institution did need to change. But whether she was right about what it should change into is an open question that will be answered in the coming months," he says. "The redevelopment has cost the entire $£ 15$-million property portfolio and the stakes are extremely high."

Last month, Quentin Pankhurst, deputy director of the London Centre for Nanotechnology, was appointed Catlow's successor. As director of the DFRL he will oversee a team of 15 permanent staff, including three principal investigators as well as several PhD students and postdocs. "I want to create a highly interdisciplinary, close-knit unit here," says Pankhurst, who will retain an affiliation with UCL, which is jointly financing the lab with the Royal Institution. Pankhurst's group will explore health-care biomagnetics, using nanopar-

\section{"We want to show ticles attached to antibodies to that scientists are locate and treat human too." cancers - tech- niques that hark}

back to Faraday's electromagnetic-induction experiments in the early days.

The group will take up 750 square metres of lab space, roughly a third of that available. The rest will go to small start-up companies not affiliated with the DFRL.

Part of Pankhurst's lab will be on public view. "We want to show that scientists are human too," he says. "The open lab won't be populated minute-by-minute, but visitors will see Mössbauer and X-ray techniques as and when the scientists use them."

Pankhurst dismisses concerns that research will play second fiddle to outreach programmes. The Royal Institution's mission statement from 1799 compels it "to facilitate the general introduction of useful inventions and improvements; and to teach...the application of science for the common purposes of life". According to Pankhurst: "These two aspects, which we might now call technology transfer and public engagement, have been and still are central tenets of the Royal Institution." Matt Brown

See Books and Arts, page 595.

\section{Climate anomaly is an artefact}

The humble bucket turns out to be at the bottom of a perplexing anomaly in the climate records for the twentieth century.

The time series of land and ocean temperature measurements, begun in 1860 , shows a strange cooling of about $0.3^{\circ} \mathrm{C}$ in the global mean temperature in 1945, relative to the 1961-90 average. The sharpness of the drop stands out even more if the signatures of internal climate variability, such as those associated with El Niño events, are filtered from the record.

This cooling at the end of the Second World War is one of several temperature drops in the record. But unlike others, such as the 1991 cooling caused by the eruption of Mount Pinatubo in the Philippines, it is limited to ocean temperatures and is not associated with any known climatic or geological phenomenon. The nuclear explosions in 1945 over Hiroshima and Nagasaki were ruled out as a possible cause because they are thought to have had no impact on global temperature. Other theories proposed as explanations for the cooling include a massive 1940s El Niño event that had somehow slipped attention, or that it was the result of sulphate aerosols from burning dirty coal. But neither of these was convincing.

A US-British team of climate scientists has now found a surprisingly simple explanation for the long-standing conundrum (page 646). It turns out that the mysterious drop is due to differences in the way that British and US ships' crews measured the sea surface temperature (SST) in the 1940s.

Only a few SST measurements were made during wartime, and almost exclusively by US ships. Then, in the summer of 1945, British ships resumed measurements. But whereas US crews had measured the temperature of the intake water used for cooling the ships' engines, British crews collected water in buckets from the sea for their measurements. When these uninsulated buckets were hauled from the ocean, the temperature probe would get a little colder as a result of the cooling effect of evaporation. US measurements, on the other hand, yielded slightly higher temperatures due to the warm engine-room environment.

The standard logbook entries made at the time contain no information about how the measurements were taken, so the cause was overlooked, says David Thompson, first author on the paper and an atmospheric scientist at the State University of Colorado in Boulder. As a result, the bias - which, although small, was large enough to produce the sharp drop in global mean temperature - was never adjusted for.

"The time series is one of the great climate records we have," Thompson says. "During a sabbatical in Britain, I revisited work that I had started a long time ago, and it suddenly occurred to me that the mid-1940s cooling might not necessarily have physical causes."

Thompson discovered the explanation after questioning maritime experts from different countries about the history of shipping, and searching the scientific literature and international databases for scattered bits of relevant information.

"We always thought the observed cooling was real," says Phil Jones, a climate researcher at the University of East Anglia, Norwich, UK, who carried out the study with Thompson. "We did know that there were fewer measurements during the war than before and thereafter, but we simply made wrong assumptions on how and by whom the measurements were taken," he says. "It is pretty clear now that the bias is instrumental.

"It is welcome news for climate modellers. The post-war temperature anomaly has been grossly outside the range of all computer-based climate reconstructions considered by the Intergovernmental Panel on Climate Change (IPCC), and it was prominently featured in the group's 2007 summary for policy-makers.

"The unusual up and down in SSTs in the 1940 s stood out like a sore thumb in the past," says Susan Solomon, a senior scientist at the US National Oceanic and Atmospheric Administration (NOAA) in Boulder, Colorado, and co-chair of the IPCC working group on the physical basis of climate change. "We couldn't explain it, so we showed all the fingers, sore thumb and all," she says.

Climate researchers can now start setting the twentieth-century temperature record straight. The abrupt drop in 1945 will then probably disappear, but what the corrected time series will look like is not yet clear.

And further corrections may come. For example, the gradual shift since the 1970s from (warm-biased) ship-based measurements to (cold-biased) drifting buoys has probably led to a slight underestimate of SST warming, says Richard Reynolds of NOAA's National Climatic Data Center in Asheville, North Carolina. "More data problems will undoubtedly come along, if likely of smaller magnitude," he says.

Climate researchers know from past experience that satellite sensors, radiosondes and ocean profilers are prone to bias. Land measurements are considered much more robust. Climate scientists should think about data quality more often, says Jones, so that there is no opportunity for incorrect data to sow seeds of doubt in people's minds about the reality of climate change.

Quirin Schiermeier 